\title{
Indirect effects of the availability of capelin and fishery discards: gull predation on breeding storm-petrels
}

\author{
Ian J. Stenhouse ${ }^{*}$, William A. Montevecchi \\ Biopsychology Programme, Memorial University of Newfoundland, St. John's, Newfoundland A1B 3X9, Canada
}

\begin{abstract}
The Northwest Atlantic has undergone largescale perturbations which have had profound effects on pelagic food webs. Over the past century, the increasing availability of human refuse and fishery discards have promoted the growth of Larus gull populations. During the 1990s, cold surface-water events have delayed the inshore movements of spawning capelin Mallotus villosus and fisheries closures have eliminated massive tonnages of discards. These circumstances have interacted to intensify food stress on gulls. We investigated gull predation in a large colony of Leach's storm-petrels Oceanodroma leucorhoa as an indirect consequence of the availability of prey and fishery discards. Predation did not differ between storm-petrels nesting in forest and open habitats even though gull nests were more often in close proximity to storm-petrel burrows in open habitat. In 1996 and 1997, gull predation on storm-petrels varied seasonally, with a significant decrease following the inshore movement of spawning capelin, a primary food that gulls consume and feed to their chicks. Capelin availability occurred considerably later in 1997, when gull predation on stormpetrels was greater and prolonged. The intensity of gull predation on storm-petrels appears to depend on the availability of spawning capelin inshore.
\end{abstract}

KEY WORDS: Indirect effects - Fishery discards - Capelin . Predation Gulls Storm-petrels

During the past century, and particularly during recent decades, the Northwest Atlantic has undergone large-scale natural and anthropogenic perturbations. Long-term trends in the Northwest Atlantic involve a general warming of surface-waters (Colbourne et al. 1994, Drinkwater 1996) and major increments in the technological sophistication and intensity of fishing activities (Warner 1977, Hutchings \& Myers 1995). Rapid-onset, short-term changes, during the early 1990s, include anomalous cold surface-water events

•E-mail: iansten@play.psych.mun.ca
(Drinkwater 1996, Montevecchi \& Myers 1996) and the closure of the Eastern Canadian ground-fishery. The interactive effects of these perturbations were initially detected in dietary shifts (Montevecchi \& Myers 1995, 1997) and reproductive success (Regehr \& Montevecchi 1997) of seabirds. These oceanographic and anthropogenic perturbations have had profound influences on pelagic food webs on the Newfoundland Shelf. For example, changes in the movement patterns of migratory pelagic fish and squid were attributed to cold surface-waters in the Northwest Atlantic (Montevecchi \& Myers 1995, 1996, 1997). Second-order or indirect effects of these interactions have been seen in breeding failures of surface-feeding seabirds (Regehr \& Montevecchi 1997). Owing to ecosystem complexity (Patten 1991, Lavigne 1996), other indirect effects at other trophic levels may take longer to detect.

Gull populations, particularly those of herring gulls Larus argentatus, have increased markedly in the Northwest Atlantic since the beginning of the 20th century (Kadlec \& Drury 1968, Drury 1973, Howes \& Montevecchi 1993, Chapdelaine \& Rail 1997). As is the case with gulls and skuas in other oceanographic regions (Furness et al. 1992, Oro et al. 1996, Phillips et al. 1997), the range expansion and population growth of gulls in the Northwest Atlantic has been supported by an increasing availability of human refuse and fishery discards (Kadlec \& Drury 1968, Drury 1973). However, since the initiation of the Eastern Canadian ground-fishery moratorium in 1992, huge tonnages of fishery discards from vessels and processing plants have no longer been available. Thus, the anthropogenically elevated gull populations have been forced to seek alternative food sources, and predatory pressures on other seabirds increased considerably during the 1990s (Regehr \& Montevecchi 1997, see also Russell \& Montevecchi 1996). These developments, in conjunction with anomalous cold water events in the 
early 1990s (Drinkwater 1996), which delayed the inshore movements of spawning capelin Mallotus villosus by 4 wk or more (Carscadden \& Nakashima 1997), produced intense food stress on gulls (see Howes \& Montevecchi 1993, Russell \& Montevecchi 1996, Regehr \& Montevecchi 1997).

Gulls are major predators on Leach's storm-petrels Oceanodroma leucorhoa at breeding colonies, where predation risk is an important aspect of habitat suitability (Lima \& Dill 1990, Stenhouse 1998). Leach's storm-petrel is the smallest and most abundant seabird breeding in the Northwest Atlantic (Montevecchi et al. 1992) and the species' major ecological traits (i.e. coloniality on remote islands, nocturnality, burrownesting, pelagic-feeding) appear to have been largely shaped by predator avoidance (Sklepkovych \& Montevecchi 1989, Huntington et al. 1996).

We investigated gull predation on Leach's stormpetrels nesting in forests and open meadows in a large colony on Great Island, Newfoundland, Canada, in relation to the timing of the availability of the gulls' primary prey, spawning capelin. We hypothesized that gull predation on storm-petrels would be highest in close proximity to nesting gulls and most intense prior to the arrival and availability of capelin inshore.

Methods. This study was conducted on Great Island $\left(47^{\circ} 11^{\prime} \mathrm{N}, 52^{\circ} 49^{\prime} \mathrm{W}\right)$ in the Witless Bay Ecological Seabird Reserve, Newfoundland, Canada, from June to September 1996 and from May to August 1997. The island is approximately $1200 \mathrm{~m}$ long (N-S) and ranges from 150 to $700 \mathrm{~m}$ wide ( $\mathrm{E}-\mathrm{W}$ ) and has a precipitous rocky shoreline, topped by steep grassy slopes, levelling out to gently sloping grass-Rubus meadows and a central area of dense conifers, predominantly dwarfed balsam fir Abies balsamea and black spruce Picea mariana. Nine seabird species breed on the island, including estimated populations of 340000 pairs of Leach's storm-petress; 123000 pairs of Atlantic puffins Fratercula arctica; 23000 pairs of black-legged kittiwakes Rissa tridactyla; 3000 pairs of common murres Uria aalge; 2770 pairs of herring gulls; and up to 80 pairs of great black-backed gulls Larus marinus (Cairns et al. 1989, Rodway et al. 1996).

'Forest' habitat was defined as an area of grass, shrub or fern vegetation and/or bare peat under a dense canopy of coniferous trees, and 'open' habitat was defined as an area of grass and shrub vegetation open to the sea and sky. In 1997, storm-petrel burrows were counted in 50 random $2 \times 2 \mathrm{~m}$ plots established in each habitat, and assessed for occupancy (i.e. egg laid) during 3 visits over the season (Stenhouse 1998). The distance from the central point of each plot to the nearest gull nest was measured along the ground to the nearest $0.1 \mathrm{~m}$. Nests more than $25 \mathrm{~m}$ from the plot, or where no nests were found, were recorded as
$>2.5 \mathrm{~m}$. Gull predation on storm-petrels was examined from June to September 1996, and from May to August 1997. A $2 \mathrm{~m}$ wide, $435 \mathrm{~m}$ transect, established in early June 1996, passed through each habitat type and a herring gull colony. All evidence of storm-petrels killed (clusters of loose feathers on the ground) and regurgitated by gulls (boluses of oily feathers and/or bones) along the transect were recorded and removed weekly. On Great Island, gulls appear to catch storm. petrels on the ground at night and kill-sites were assumed to indicate capture locations. However, regurgitations are not indicative of the capture location and were used as an overall index of gull predation on the island. Most regurgitations were found within the gull colony, yet no storm-petrels were found to have been killed in this area. The number of storm-petrels killed was standardized by applying the mean burrow occupancy for each habitat (Stenhouse 1998), enabling comparison of the number of storm-petrels killed per occupied burrow in relation to habitat, year, and the availability of capelin. The inshore movement and availability of capelin to gulls and other seabirds in Witless Bay was indicated, as in previous studies (Rodway \& Montevecchi 1996), by the appearance of capelin in the diets of common murre and Atlantic puffin chicks on Great Island (C. Walsh \& S. Wilhelm pers. comm.). These dates coincided with observations of capelin spawning inshore at Bauline South, a small community approximately $2 \mathrm{~km}$ west of Great Island.

The proportion of plots $<25 \mathrm{~m}$ from a gull nest in each habitat were compared using the $G$-test of independence, employing the Williams' correction for a $2 \times 2$ table (Sokal \& Roh.lf 1995). Statistical comparison of storm-petrels killed per occupied burrow were made using a General Linear Model (Data Desk 5.0, Data Description Inc., Ithaca, NY). We applied arcsin square-root transformations to proportional data prior to analysis (Sokal. \& Rohlf 1995). Error distributions were examined for homogeneity, normality and independence of residuals (Simpson \& Schneider unpubl.) and found to be acceptable.

Results and discussion. Proximity of gull nests to burrow plots ranged from 2.1 to $>25 \mathrm{~m}$ in forest and from 0.9 to $>25 \mathrm{~m}$ in open habitat. The proportion of burrow plots $<25 \mathrm{~m}$ from a gull nest was significantly higher in open $(96 \%)$ than in forest $(36 \%)$ habitat $\left(G_{\text {adj }}\right.$ $=45.3 \mathrm{df}=1, \mathrm{p}<0.001)$. In 1996, a total of $49 \mathrm{kills}$ and 186 regurgitations, and in 1997, a total of 175 kills and 452 regurgitations were recorded along the transect. However, the number of storm-petrels killed per occupied burrow did not differ significantly between forest and open habitat in 1996 and $1997\left(F_{1,51}=1.94\right.$, $\mathrm{p}=0.17$ ). Interestingly, the number of storm-petrels killed per occupied burrow varied seasonally in both years, with a significantly greater number of storm- 
petrels killed per occupied burrow prior to the availability of capelin (Fig. $1 ; F_{1,51}=25.9, \mathrm{p}<0.001$ ). Overall, significantly more storm-petrels were killed per occupied burrow in 1997 than in $1996\left(F_{1,51}=13.2\right.$, $p<0.001$ ). Capelin appeared in the diet of common murre and Atlantic puffin chicks in the third week of June 1996, and 2 wk later in the first week of July 1997. The number of storm-petrels killed per occupied burrow (Fig. 1) and the total number of regurgitated storm-petrels (Fig. 2) show similar patterns in both years. This correspondence suggests that the number of storm-petrels killed per occupied burrow is a reasonable measure of overall predation by gulls on Great Island.

Gull nests were consistently closer to storm-petrel burrows in open than in forest habitat. Pierotti \& Annett (1991) found herring gulls that specialized in preying on storm-petrels nested significantly more often than expected in open meadows. In view of the proximity of gull nests and the specialist nature of these individuals, predation risk for Leach's stormpetrels might be expected to be greater in open habitat than in forest. However, the standardized predation rates (storm-petrels killed per occupied burrow) that we found did not differ significantly between open and forest habitats.

In both 1996 and 1997, predation was generally highest in May and June, and lowest in July (Fig. 1).

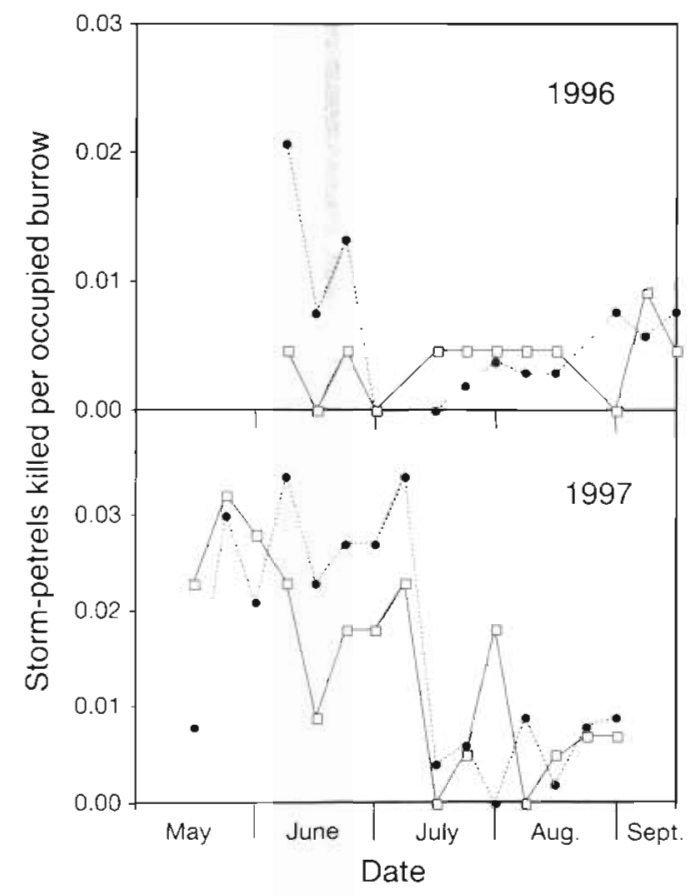

Fig. 1 Number of Leach's storm-petrels killed per occupied burrow in open (D) and forest ( ) habitats in 1996 and 1997 on Great Island, Newfoundland, Canada. The shaded bar represents the timing of the inshore movement of capelin

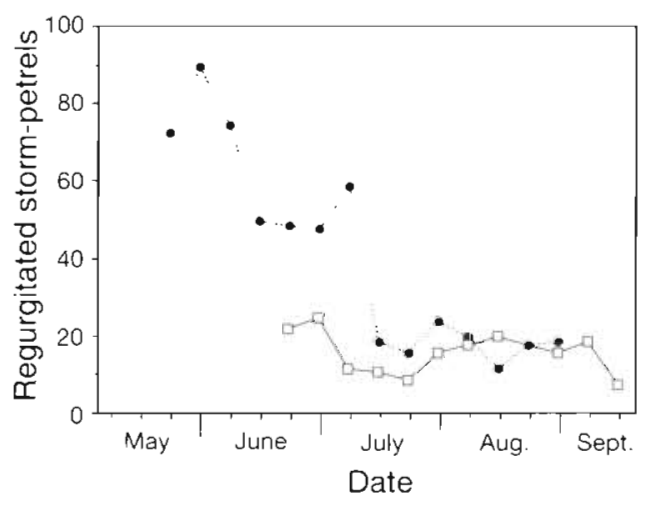

Fig. 2. Number of regurgitated Leach's storm-petrels found along transect in 1996 (ㅁ) and 1997 (•) on Great Island, Newfoundland

Storm-petrels killed per occupied burrow (Fig. 1) and overall predation (Fig. 2) decreased precipitously on Great Island, at a time when storm-petrels remained widely available and gull energy requirements were high. The sudden decrease in gull predation on stormpetrels, in late June 1996 and early July 1997, coincided with the inshore movement of spawning capelin (Fig. 1). In 1997, when the inshore movement of capelin was 2 to 3 wk later, gull predation on storm-petrels was higher and prolonged. In the late 1970s, herring gulls on Great Island exhibited dietary shifts from storm-petrels, blue mussels Mytilus edulis and refuse to capelin and short-finned squid Illex illecebrosus immediately after gull chicks hatched in early- to mid-June (Pierotti 1983, Pierotti \& Annett 1987). The dietary shift by gulls, observed indirectly in this study through storm-petrel depredation, occurred up to $3 \mathrm{wk}$ later than in the 1970 s and is consistent with the later inshore arrival of capelin (Carscadden \& Nakashima 1997). As capelin have spawned later in the 1990s (Montevecchi \& Myers 1992, Carscadden \& Nakashima 1997), the period of high predation by gulls on storm-petrels appears to have been prolonged. Moreover, as capelin have exhibited an increasing tendency to spawn offshore during the 1990s (Shackell et al. 1994), gulls may be preying more extensively on storm-petrels throughout the breeding season, as has been demonstrated for gull predation on kittiwakes in Newfoundland (Regehr \& Montevecchi 1997). A similar situation has also been observed in Shetland, where great skuas Catharacta skua switched to predation on seabirds after a dramatic decline in the availability of sandeels Ammodytes marinus (Hamer et al. 1991).

Storm-petrel mortality due to gull predation at colonies is considered to involve largely nonbreeding storm-petrels (Morse \& Buccheister 1977, Huntington et al. 1996). However, nonbreeding storm-petrels tend to prospect at colonies late in the season. Waters 1964 , 
Scott 1970, Furness \& Baillie 1981), e.g. July and August in Newfoundland. If nonbreeding stormpetrels mainly visit the colony on Great Island late in the season, as supported by casual observations of increased prospecting activity in late July (pers. obs., C. Walsh pers comm.), then the prolonged predation that we document may be directed at breeding stormpetrels and have little effect on nonbreeders.

In conclusion, the intensity of predation pressure imposed on Leach's storm-petrels by gulls appears to be associated with the temporal availability of capelin. Predation pressure by gulls (1) has likely increased with increasing gull populations, (2) is intensified by the elimination of discards due to fishery closures, and (3) is extended by the delayed inshore arrival of capelin. Clearly, the availability of forage fishes (Springer \& Speckman 1997) and fishery discards (Tasker et al. unpubl.) can have both immediate effects on the reproductive success of seabirds and more subtle, cumulative indirect effects on interspecific interactions that may be much more far-reaching (e.g. Regehr \& Montevecchi 1997). It is essential to delineate the indirect effects of prey availability and of fishing activity on seabird community interactions to better understand the complexities and implications of the largescale ecosystem perturbations which have taken place in the Northwest Atlantic and elsewhere.

Acknowledgements. We are indebted to Anne Storey, Carolyn Walsh, Louise Copeman, Kelly Squires and Sabina Wilhelm for field assistance and to Mark Hipfner and 3 anonymous reviewers for helpful comments on an earlier draft of this manuscript. Research was supported by an NSERC Individual Operating Grant to W.A.M., and a Memorial University of Newfoundland Graduate Fellowship to I.J.S. We are grateful to Newfoundland and Labrador Parks Division, particularly Glen Ryan and Doug Ballam, for permission to work on Great Island in the Witless Bay Ecological Seabird Reserve.

\section{LITERATURE CITED}

Cairns DK, Montevecchi WA, Threlfall W (1989) Researcher's guide to Newfoundland colonies. Occ Pap Biol No. 14. Memorial University of Newfoundland, St. John's

Carscadden JE, Nakashima BS (1997) Abundance and changes in distribution, biology and behavior of capelin in response to cooler waters of the 1990s. Proc Int Symp Role of Forage Fishes in Marine Ecosystems. Alaska Sea Grant College Prog Rep 97-01:457-468

Chapdelaine G, Rail JF (1997) Relationship between cod fishery activities and the population of herring gulls on the North Shore of the Gulf of St. Lawrence, Quebec, Canada. ICES J Mar Sci 54:708-713

Colbourne E, Narayana S, Prinsenberg S (1994) Climatic changes and environmental conditions in the Northwest Atlantic, 1970-1993. ICES Mar Sci Symp 198:311-322

Drinkwater KF (1996) Climate and oceanographic variability in the Northwest Atlantic during the 1980s and early1990s. J Northw Atl Fish Sci 18:77.97
Drury WH (1973) Population changes in New England seabirds. Bird-Banding 44:267-313

Furness RW, Baillie SR (1981) Factors affecting capture rate and biometrics of storm-petrels on St Kilda. Ring Migr 3: $137-148$

Furness RW, Ensor K, Hudson AV (1992) The use of fishery waste by gull populations around the British Isles. Ardea 80:105-113

Hamer KC, Furness RW, Caldow RWG (1991) The effects of changes in food availability on the breeding ecology of great skuas Catharacta skua in Shetland. J Zool (Lond) 223:175-188

Howes LA, Montevecchi WA (1993) Population trends and interactions among terns and gulls in Gros Morne National Park, Newfoundland. Can J Zool 71:1516-1520

Huntington CE, Butler RG, Mauk RA (1996) Leach's stormpetrel Oceanodroma leucorhoa. In: Poole A, Gill F (eds) The birds of North America no. 233. American Ornithologists' Union, Washington, DC

Hutchings JA, Myers RA (1995) What can be learned from the collapse of a renewable resource? Atlantic cod Gadus morhua of Newfoundland and Labrador. Can J Fish Aquat Sci 51:2126-2146

Kadlec JA, Drury WH (1968) Structure of the New England herring gull population. Ecology 49:644-676

Lavigne DM (1996) Ecological interactions between marine mammals, commercial fisheries, and their prey: unravelling the tangled web. In: Montevecchi WA (ed) Studies in high latitude seabirds 4 . Trophic relationships and energetics of endotherms in cold ocean systems. Can Wildl Ser Occ Pap 91, Ottawa, p 59-71

Lima SL, Dill LM (1990) Behavioural decisions made under risk of predation: a review and prospectus. Can J Zool 68: $619-640$

Montevecchi WA, Myers RA (1992) Monitoring fluctuations in pelagic fish availability with seabirds. Can Atl Fish Study Advis Comm Res Doc 92/94

Montevecchi WA, Myers RA (1995) Prey harvests of seabirds reflect pelagic fish and squid abundance on multiple spatial and temporal scales. Mar Ecol Prog Ser 117:1-9

Montevecchi WA, Myers RA (1996) Dietary changes in seabirds reflect shifts in pelagic food webs. Sarsia 80: 313-322

Montevecchi WA, Myers RA (1997) Centurial and decadal oceanographic influences on changes in northern gannet populations and diets in the Northwest Atlantic: implications for climate change. ICES J Mar Sci 54:608-614

Montevecchi WA, Birt-Friesen VL, Cairns DK (1992) Reproductive energetics and prey harvest of Leach's stormpetrels in the Northwest Atlantic. Auk 73:823-832

Morse DH, Buchheister CW (1977) Age and survival of breeding Leach's storm-petrels in Maine. Bird-Banding 48:341-349

Oro D, Jover L, Ruiz X (1996) Influence of trawling activity on the breeding ecology of a threatened seabird, Audouin's gull Larus audouinii. Mar Ecol Prog Ser 139:19-29

Patten BC (1991) Network ecology: indirect determination of the life-environment relationship in ecosystems. In: Higashi M, Burns TP (eds) Theoretical ecosystem ecology: the network perspective. Cambridge University Press, London, p 288-351

Phillips RA, Catry P, Thompson DR, Hamer KC, Furness RW (1997) Inter-colony variation in diet and reproductive performance of great skuas Catharacta skua. Mar Ecol Prog Ser 152:285-293

Pierotti R (1983) Gull-puffin interactions on Great Island, Newfoundland. Biol Conserv 26:1-14 
Pierotti R, Annett CA (1987) Reproductive consequences of dietary specialization and switching in an ecological generalist. In: Kamil AC, Krebs J, Pulliam R (eds) Foraging behaviour. Plenum, New York, p 417-442

Pierotti R, Annett CA (1991) Diet choice in the herring gull: constraints imposed by reproductive and ecological factors. Ecology 72:319-328

Regehr HM, Montevecchi WA (1997) Interactive effects of food shortage and predation on breeding failure of blacklegged kittiwakes: indirect effects of fisheries activities and implications for indicator species. Mar Ecol Prog Ser 155:24.9-260

Rodway MS, Montevecchi WA (1996) Sampling methods for assessing the diets of Atlantic puffin chicks. Mar Ecol Prog Ser 144:41-55

Rodway MS, Montevecchi WA, Chardine JW (1996) Effects of investigator disturbance on breeding success of Atlantic puffins Fratercula arctica. Biol Conserv 76: 311-319

Russell JO, Montevecchi WA (1996) Predation on adult puffins Fratercula arctica by great black-backed gulls Larus marinus at a Newfoundland colony. Ibis 138: $791-794$

Editorial responsibility: Otto Kinne (Editor),

Oldendorf/Luhe, Germany
Scott DA (1970) The breeding biology of the storm petrel. PhD thesis, University of Oxford

Shackell NL, Carscadden JE, Miller DS (1994) Migration of pre-spawning capelin Mallotus villosus as related to temperature on the northern Grand Bank, Newfoundland. ICES J Mar Sci 51:107-114

Sklepkovych BO, Montevecchi WA (1989) The world's largest known nesting colony of Leach's storm-petrels on Baccalieu Island, Newfoundland. Am Birds 43:38-42

Sokal RR, Rohlf FJ (1995) Biometry: the principles and practice of statistics in biological research, $3 \mathrm{rd}$ edn. Freeman, New York

Springer AM, Speckman SG (1997) A forage fish is what? Summary of the symposium. Proc Int Symp Role of Forage Fishes in Marine Ecosystems. Alaska Sea Grant College Prog Rep 97-01:773-805

Stenhouse IJ (1998) Habitat utilization and breeding success of Leach's storm-petrel Oceanodroma leucorhoa. MSc thesis, Memorial University of Newfoundland, St. John's

Warner WW (1977) Distant water: the fate of the North Atiantic fisherman. Little, Brown, Toronto

Waters E (1964) Arrival times and measurements of small petrels on St Kilda. Brit Birds 57:309-314

Submitted: December 21, 1998; Accepted: May 7, 1999 Proofs received from author(s): July 5, 1999 